\title{
Value-adding and Value-extracting Entrepreneurship at the Margins
}

\author{
Kirk Frith, University of Lincoln, Lincoln, United Kingdom \\ Gerard McElwee, University of Lincoln, Lincoln, United Kingdom
}

\begin{abstract}
Empirical data is reported from two case studies on the methods used to establish and grow the businesses of two entrepreneurs operating in very different environments: one legitimate, the other illegitimate. Both utilize strong social skills to legitimize their behaviours but neither can be considered as mainstream or conventional entrepreneurial actors. The findings suggest that, despite the very different outcomes associated with their actions, both entrepreneurs exhibit similar enterprising skills and managerial capabilities as found in entrepreneurs engaged in non-marginal activities.

RÉSUMÉ. On rapporte ici des données empiriques, provenant de deux études de cas, sur les méthodes utilisées pour mettre en place et exploiter deux entreprises opérant en milieux fort différents—l'un légitime et l'autre non. Les deux entrepreneurs se servent de solides aptitudes sociales pour légitimer leurs comportements, mais ni l'un ni l'autre ne peuvent être tenus pour des acteurs entrepreneuriaux conventionnels ou de type majoritaire. Nos conclusions démontrent qu'en dépit des résultats très différents découlant de leurs actions, ces deux entrepreneurs possèdent des capacités d'initiative et des compétences de gestion similaires à celles des entrepreneurs engagés dans des activités non marginales.
\end{abstract}

\section{Introduction}

Entrepreneurship is widely regarded as a driver of economic development and growth (Harper, 2003). Williams (2008) argues there appears to be a clear distinction between "necessity-driven" entrepreneurs pushed into entrepreneurship because other options for work are absent or unsatisfactory, and "opportunity-driven" entrepreneurs who engage in entrepreneurship out of choice. In this paper, however, we utilize a different bifurcation of entrepreneurs operating at the margins: "value-adding" and "value-extracting" entrepreneurs. To do this, empirical evidence will be presented from interviews with two entrepreneurs.

This paper will first define what is meant by entrepreneurship at the margins. It will then comment on the bifurcation of entrepreneurs at the margin as "value-adding" or "value-extracting" and the extent to which the activity of these entrepreneurs can become accepted and/or tolerated by external actors particularly if an ethical code is adopted and followed. This will be illustrated and explored by two case studies; one of a "social entrepreneur," and one of a drug dealer. Both entrepreneurs, as will be seen, exhibit characteristics, for example, strategic awareness, opportunity spotting and networking, usually associated with more traditional notions of entrepreneurship. The final section will bring together some conclusions about the relevance and insights that can be drawn by deliberately dichotomizing "value-adding" and "value-extracting" entrepreneurship as a mechanism for understanding the challenges and constraints faced by entrepreneurs who operate at the margins.

The first task is to define what is meant by "entrepreneurship at the margins," "valueadding," and "value-extracting." Clearly, entrepreneurship at the margins can be located 
within what Williams (2006) refers to as the informal economy but, and as will be seen, this is not necessarily a specific characteristic.

\section{Entrepreneurship at the Margins}

The promotion of enterprise and entrepreneurship has tended to focus on business startup in the formal sector and, as a consequence, has paid little attention to the nature and types of entrepreneurship that occur at the margins. Research into entrepreneurship at the margins has sought to explore why certain groups and individuals, despite not fitting the conventional description of the entrepreneur, have managed to engage in enterprise and entrepreneurship. As an academic discipline, entrepreneurship has always been concerned with understanding how entrepreneurs work at and beyond the boundaries of what is known and, occasionally, of what is accepted in the pursuit of profits. However, the majority of research exploring entrepreneurship at the margins has tended to focus on the marginalized entrepreneur rather than on entrepreneurship at the margins per se. Cases of entrepreneurship involving minority entrepreneurs (Galloway, 2007), illegal enterprises (Rehn and Taalas, 2004; Smith, 2007; Williams, 2008), drug dealers (Frith and McElwee, 2008a, 2008b) and other such marginal activities (Storr and Butkevich, 2007) have been the most common instantiations of this type of research to date. The individuals involved in these enterprises have been commonly portrayed as deviant and often as social outcasts who operate at the margins of society. This type of research has, by and large, documented cases of entrepreneurship that mainstream, and hence more widely accepted, entrepreneurship research has tended to ignore.

The activities pursued in this type of research have generally been small in scale and to have had relatively little impact upon the wider community in which they have been situated. Frith and McElwee (2008b) argue, however, that these actors have both an economic and a social function, both of which offer critical but in themselves insufficient insights into entrepreneurship at the margins. Nevertheless, as Galloway (2007: 271) suggests, research exploring entrepreneurship at the margins has helped to challenge "current stereotype-based knowledge" and draw attention to the heterogeneity or diversity of entrepreneurial activities and individuals which, according to Schindutte et al. (2005: 27-28), has furthered the "development of ... theory regarding the larger population."

In much of the recent literature on entrepreneurs' motives, there has been a tendency to differentiate between necessity- and opportunity-driven entrepreneurs (Harding et al., 2006; Maritz, 2004; Minniti et al., 2006; Perunovic, 2005). This paper argues, however, that squeezing entrepreneurs into one side or the other of this either/or dichotomy oversimplifies entrepreneurs' motives and obfuscates how they change over time. This necessity/opportunity dualism is not only too simplistic to explain entrepreneurs' motives since both necessity and opportunity factors are commonly involved, but there is often a temporal fluidity in their motives, usually from necessity-oriented to opportunity-oriented factors. The lived practice is therefore more integrative and dynamic than captured by this static either/or dualism. Furthermore, concentrating exclusively on the motives that underlie entrepreneurial action necessarily avoids discussion of the social consequences of their activities. As such, we turn to another important, though frequently overlooked dualism within the entrepreneurship literature, that of value-adding and value-extracting entrepreneurship.

\section{"Value-adding" and "Value-extracting" Entrepreneurship}

For Kirzner, a substantial proportion of entrepreneurial activity does not occur at the 
margins, does not enrich or expand the totality of human knowledge but, nevertheless, helps to improve market efficiency and overall economic welfare (Kirzner, 1973). Entrepreneurs who are engaged in activities of arbitrage, for example, are considered as value-adding entrepreneurs as they work to ensure that resources are put to their most productive or profitable use. Value-adding entrepreneurship can therefore be defined as those types of entrepreneurial activities which are legitimate but which do little to change or affect the margins within which they operate. Value-extracting entrepreneurship can be defined as those types of entrepreneurial activities that occur within existing margins but which impoverish or damage the community within which they occur. Illegal enterprises, including drug-dealing and fencing (selling "hot" or stolen goods), for example, are perhaps the most common forms of this type of activity and tend to follow or mimic very closely legitimate forms of entrepreneurship. Indeed, removing or ignoring the moral or ethical issues associated with such activities renders them almost imperceptible from traditional forms of entrepreneurship.

Smith (2007: 245) argues that entrepreneurship at the margins should move away from mainstream or typical cases of entrepreneurship and instead focus on cases of entrepreneurship that are at the "edge of the known and accepted" as there are "many areas of entrepreneurship that exist at the boundaries of our knowledge and that are worthy of further study." Although this definition focuses attention upon entrepreneurship at the margins as opposed to entrepreneurship on the margins, it makes it clear that there is an aspect of entrepreneurship (level of acceptance) that is very important to the growth and survival of such endeavors. As argued above, there are entrepreneurs working within the margins of what is known and accepted; however, there are also entrepreneurs whose activities help to influence and shape the margins themselves. As such, we take the view that research should be concerned with all types of entrepreneurial activities at the margins which themselves are in the process of being challenged, reconsidered, redefined, and, in certain circumstances, redrawn altogether. This paper explores, with specific reference, the processes and mechanisms used to achieve and leverage degrees of acceptance.

Entrepreneurship at the margins poses ethical and moral issues for both the entrepreneurs themselves and the actors with whom they interact. For some commentators, entrepreneurship and ethics appear as conflicting forces. Wempe (2005), for example, argues that, until very recently, entrepreneurship and ethics were regarded as naturally opposed:

There is the view that ethics (together with the law) limits entrepreneurship. Ethics (and laws) formulates standards that give entrepreneurship some space. Ethics and entrepreneurship are seen as two entirely separate areas. Entrepreneurship is viewed as amoral, or perhaps even as immoral. Entrepreneurs need to exploit opportunities and consider all options. This should occur within the boundaries set by the law, and complemented by ethics. (Wempe, 2005: 215)

Atherton (2004) argues that as a result of this dynamic, the majority of entrepreneurship research has deliberately overlooked or simply not considered the ethical dimension. A reason for this, according to Wempe, is that entrepreneurship has traditionally been understood as an economic pursuit in which self-interest or the interests of small groups of individuals predominate-especially in situations where the future of a business is at stake and the investment and future well-being of the owner is in jeopardy (Schramm, 2006). As a consequence, entrepreneurship and ethics have tended to be kept as separate academic disciplines (Hannafey, 2003). Given that entrepreneurship involves exploiting 
better or superior information than is possessed by trading counterparts (Kirzner, 1973), ethical considerations appear particularly intractable. As a consequence, the entrepreneur has been most commonly presented as a lone individual, a maverick hero whose skills and expertise in opportunity-spotting are singularly concerned with profit maximisation (Nodoushani, and Nodoushani, 2000).

However, depictions of the entrepreneur as a dispassionate and efficient calculator of economic costs and benefits neglects that fact that entrepreneurs are socially active individuals whose actions and behaviours alter, both positively and negatively, the environment within which they and others both work and live. Furthermore, such characterisations do not resonate with real-world accounts and experiences in which entrepreneurs are often seen to be at the forefront of social change. To illustrate this dynamic, two very different case studies are presented in order to explore in more detail the challenges facing entrepreneurial individuals who are prepared to initiate ventures that are on or transgress the boundaries of what is known and/or accepted.

The first case study used in this paper charts the developmental history of a social enterprise based in the East Midlands of the UK, while the second case study charts the developmental history of a drug-dealing circle also based in the East Midlands of the UK. This theoretical approach is in keeping with the suggestion of Etzioni (1987: 175), who argued that the activities of entrepreneurs help to change obsolescent and ossified societal patterns:

entrepreneurship is studied here as the force that promotes societal reality testing. Societal patterns (institutions, organizations, rules, etc.) tend to ossify, lagging ever more behind constantly changing environments. Entrepreneurs, by promoting new patterns, help bring society and its component units in touch with reality ... the focus here is on the contribution of entrepreneurship to the society at large and the economy embedded within it.

The two cases presented seek to explore in more detail the assertion made by Etzioni and to explore the notion of societal reality testing in greater depth.

\section{Methodology}

The entrepreneurs in both of these cases were interviewed over a number of months in 2006 by one of the authors using what has been termed the "phenomenological interview" as initially proposed by Thompson et al. (1989) and discussed by Cope, where: "the aim of the interview is to gain a first person description of some specified domain of experience" (2003: 15).

Unstructured interviews were used to allow the respondents a choice in what account they gave, thereby avoiding imposing too much form on the nature of the response. Using relatively unstructured techniques allowed the interviewees to feel free to describe their experiences in some detail without putting them either under any pressure to respond in a particular way, as much as is practicable, or indeed to push them in any particular direction. Interviewing and visiting both interviewees on a number of occasions over a period of several months also helped to develop a strong rapport between the interviewer and interviewee which, in turn, improved the interview responses both in terms of openness and honesty. 


\section{Case Study: Hill Holt Wood}

\section{History}

Hill Holt Wood, a 34-acre ancient woodland in Lincolnshire, was purchased by Karen and Nigel Lowthrop in 1995. The purchase capital of $£ 30,000$ was raised through the sale of the Lowthrops' fencing company which they had owned and managed for the previous 10 years. Hill Holt Wood was in very poor condition when Karen and Nigel first took ownership; invasive rhododendron had taken hold of large tracts of land, the drainage system had been severely damaged leaving much of the surface area of the woodland waterlogged and inaccessible, and the vast majority of the quality timber had been removed and sold. However, Karen and Nigel felt that they had the knowledge and the motivation required to restore Hill Holt Wood to its original or natural condition.

In 1996, Karen and Nigel sold their house and used the proceeds to purchase a 30-foot American Winnebago. Within weeks, Karen and Nigel had moved into the Winnebago and onto the woodland so as to save the morning/evening commute time to and from the wood as well as to demonstrate to their neighbours and the local community their commitment to the development of the site. Nigel felt strongly that the interest and support of the local community would prove essential if the project was going to succeed:

When we first arrived there was a lot of suspicion with regards to what we were doing and why we were doing it. I think people thought that we were radical environmentalists and that the wood was going to be filled with "tree-huggers" and other such types. We had to work really hard to demonstrate to our neighbours that we were genuinely interested in making a difference so we decided to try and include them in every step of the project.

In the first instance, involvement with the community took the form of simple measures such as attending local events, meeting and speaking with their neighbours and inviting as many people to come and visit them in the woodland as possible. This, Karen and Nigel felt, helped to break down some of the suspicions that they had picked up on when they first arrived, before they had time to take root.

Two years after the purchase of Hill Holt Wood, Karen and Nigel established the Hill Holt Wood Management Committee as a permanent link between themselves and the local community. The committee was designed to act in an advisory role and included representatives from a number of local organizations as well as a number of influential locals. There were many reasons given for establishing the committee, the most significant being the need to increase the input from the local community, improve the overall transparency of the project, and create a greater sense of shared ownership:

I use those words [transparency, openness, trust, inclusiveness] in reports that I write, and use them to explain how we developed the trust of the local community and how to get community support and that's why I'm always telling people everything about the business and involving as many people as possible, you know, I'm sticking to my principles, I'm saying that we are open and transparent and we will tell people how much the site is worth, how much we earn, how much the business turns over, everything!

However, despite the very obvious success enjoyed by Karen and Nigel and all those involved in and associated with Hill Holt Wood, the key challenge, convincing external 
stakeholders and organizations of the benefits of Hill Holt Wood's approach to woodland management, was still very difficult:

the farmers' union still don't see it and they still don't understand it and they still don't listen to it, they still dismiss it as a one-off, you know, they don't see how it could impact on other sites. They always say that you might do one per county, that's always been the argument, now, if I can get a mirror project set up two miles to the east of us and another one two miles to the west of us, one of which is bigger than Hill Holt, and, erm, if, if they work to the level that I think they can work, then in three years' time the total jobs employed on those three sites could be 80 , possibly 90 , with a turnover of $£ 3,500,000$, maybe $£ 4,000,000 \ldots$ now if we can do that, then they can't argue with it, they can't argue that there is an approach that they can't apply to an awful lot of farmland, to a lot of sites around the country.

In an attempt to convince outsiders of the merits of Hill Holt Wood, Nigel worked extensively and almost exclusively on promoting to others the work that was being undertaken at Hill Holt Wood. One dimension to this promotion was giving talks and presentations across the UK. However, the biggest challenge was encouraging people to come and see the woodland for themselves:

To start with it was like pulling teeth, we were just dismissed and nobody wanted to talk to us let alone to come and visit the site ... it's very difficult as a small project to get recognized, to get seen, apart from the fact that you've got no track record and the who the hell are you kind of attitudes, but there's also the fact that if you've got government departments that fund projects that they can hold them up as successes and what they don't want is some independent who's actually doing better than their funded project.

The next important step in the development of Hill Holt Wood was to make the project economically sustainable and to demonstrate the viability of their strategy. Through his contacts in the local area, Nigel discovered that there was an opportunity to provide on-site courses for local young offenders who had been excluded from mainstream education. In exchange for working with these young people and teaching them basic life skills such as teamwork and responsibility, Hill Holt Wood would receive appropriate remuneration per student per day. Nigel realized that he could use these young people to help him to achieve his vision for Hill Holt Wood and so he tailored the learning courses around improving, managing and maintaining the learning environment (i.e. the wood itself). The first group of learners arrived at Hill Holt Wood in 1998. The new direction taken by Hill Holt Wood as a result of pursuing this opportunity opened a number of new avenues and brought the project to the attention of a wider range of individuals and groups that previously would not have been interested in the project:

We've had visitors coming to the site from any number of different agencies including DEFRA [The UK government Department of Environment, Food and Rural Affairs], the DTI, [The UK government Department of Trade and Industry], the Office of the Deputy Prime Minister, the Forestry Commission; we've even had visitors from the royal family. That's what's so great about what we're doing, it appeals to so many different organizations on so many different levels. The 
more stakeholders we've got interested in Hill Holt Wood the easier we've found it to do the thing - the difficulty was in getting them here in the first place!

In 2001, Karen and Nigel were granted planning permission for the building of an ecohouse in their woodland. The planning permission for the eco-house was granted by the District Council in part recognition of the business-generated income that was beginning to come from forestry and business-related activities ancillary to forestry. However, Karen and Nigel feel that the planning permission would not have been given without the hard work and support of the local community. In keeping with this belief, Karen and Nigel elected to increase the community membership from the initial four-parish network established in 1997 to an 11-parish network by 2002, covering a total population in excess of 10,000 .

In late 2002, and at the insistence of Karen and Nigel, the Volunteer Board of Directors (VBD) took full control of Hill Holt Wood (buying Karen and Nigel out of the business for a fee well below the true market value but allowing them to proportion off a part of the woodland for their new house). The VBD asked Karen and Nigel to continue in their roles as manager and director, respectively. Selling Hill Holt Wood to the community was, according to Nigel, a key factor in ensuring the long-term sustainability of the project:

People thought we were barmy when Karen and I gave up the business and gave it to the community but we've actually done better out of it personally than if we'd stayed running it. It's interesting that the executive committee actually argued with me in favour of my salary going up! The move into becoming a social enterprise was driven by considerations of sustainability; it helps to make the business more sustainable, it helps to make the community link more stable. The real difference is how the business is becoming less dependent on me; it won't be long now until it is totally independent. I think it could survive without me... If Karen and I both left, it would, it would be too difficult at the moment but, I guess, in another year or so I think it would be fine, it might even do better!

Throughout this time, the numbers of learners arriving at Hill Holt Wood grew steadily as did the numbers of staff employed as rangers or as administrative assistants. In addition Hill Holt Wood was awarded a number of local, regional and national awards in recognition of their achievements both for enterprise and entrepreneurship as well as for their contribution in developing new approaches to helping young offenders find new meaning in their lives and careers.

With regards to the future, Karen and Nigel both feel that they have developed a business that can be used as a template for other similar projects across the country:

It's now taking that and saying that it can happen all over the country. It will be difficult to set up more projects like this along the same sort of lines; the element of community control, the element of environmental lead and the different approach to the countryside, it's difficult to win people over in the short term but we've proven that if you persist, it can be done.

However, despite the success of the project to date, the desire to convince an ever increasing audience of the merits of their approach appears not to have diminished: 


\begin{tabular}{|c|c|c|}
\hline Timeline & Key Achievements & People Employed \\
\hline 1995 & Hill Holt Wood Purchased by Karen and Nigel Lowthrop & \\
\hline 1997 & $\begin{array}{l}\text { Management committee established } \\
\text { Friends of Hill Holt Wood formed } \\
\text { Education, Environment and Financial committees established }\end{array}$ & Employs 3 staff \\
\hline 1998 & $\begin{array}{l}\text { First learners arrived (New Deal) } \\
\text { Runners up Lincolnshire Environmental Award }\end{array}$ & Employs 3 staff \\
\hline 1999 & First straw-bale building erected & Employs 3 staff \\
\hline 2001 & Planning permission granted for eco-house & Employs 3 staff \\
\hline 2002 & $\begin{array}{l}\text { "Solutions 4" learners arrive } \\
\text { Social enterprise formed } \\
\text { Investor in People standard awarded (IIP) }\end{array}$ & Employs 6 staff \\
\hline 2003 & "Employment-2-Enterprise" contract awarded & Employs 8 staff \\
\hline 2004 & $\begin{array}{l}\text { Royal visit } \\
\text { IIP retained }\end{array}$ & Employs 17 staff \\
\hline 2005 & $\begin{array}{l}\text { Adult learning inspectorate passed (Grade 2) } \\
\text { Winner Enterprising Solutions Award } \\
\text { Winner Entrepreneur of the Year Award } \\
\text { Winner Lincolnshire Environmental Award (group award) }\end{array}$ & Employs 18 staff \\
\hline
\end{tabular}

It's the underlying idea, I'm trying to win people over to the idea, to the underlying concept of sustainable development, and to the benefits that can be gained by linking the urban with the rural. It's great to be involved in a whole string of meetings now about that and talking at conferences and being sought out for conferences and so on.

\section{Discussion}

As can be seen from the case study of Hill Holt Wood, the challenges facing new and innovative businesses are often acute. Even in cases where the social benefits appear quite obvious to outsiders familiar with the project, there tends to be strong resistance when old patterns and routines and established ways of working are challenged and shown to be outmoded. Karen and Nigel attempted to overcome these challenges by taking an inclusive approach, by involving as many people as possible in their project. However, including local stakeholders in the project involved more than simply allowing them to walk around the woodland; it required full and ongoing communication between both parties. This approach allowed Karen and Nigel to develop strong relationships with the key stakeholders in the area and to gain the trust that was so critical in terms of developing and expanding the site. Once the trust of the local community had been gained, it was essential for the long-term sustainability of the business to get other, and possibly more powerful, stakeholders involved in the business. However, the challenges of involving more distant stakeholders were far greater for a number of reasons. Firstly, the greater the distance away from the site these stakeholders were, the more difficult it was to convince them to visit the site. Secondly, the less proximate these stakeholders were, the less like stakeholders they felt and so the less interest they had in the project. Nevertheless, as far as Karen and Nigel were concerned, these individuals and organizations were stakeholders and were perhaps the biggest obstacle in the way of securing the future of Hill Holt Wood. As such, Karen and Nigel expended a great deal of effort in trying to contact these stakeholders and in trying to communicate to them the benefits of adopting their approach to woodland management. 
Gradually, over time and on the crest of the "green wave," more and more individuals from across the UK began to visit and become involved in the Hill Holt Wood project, culminating in a visit from HRH the Earl of Wessex. The visits of such key individuals made a significant difference in terms of Hill Holt Wood's ability to open the doors to other stakeholders, to get them interested and to encourage them to contribute to the project.

The issues discussed here are not unique; indeed, in many ways it is the archetypal story of the entrepreneur emerging victorious against all odds. Such stories which depict hard-working and devoted individuals in pursuit of their dreams of and for a better world are pervasive. The promotion of entrepreneurship has been based largely on this type of story with the inference that individuals who are successful in their private endeavors will improve not only their own economic well-being but also that of others. Entrepreneurship, from this perspective, is understood and [re]presented as both a private and a public good. However, the prevailing assumption that underpins such stories has come under increasing scrutiny in recent years; "there are a variety of roles among which the entrepreneur's efforts can be [allocated], and some of those roles do not follow the constructive and innovative script that is conventionally attributed to that person" (Baumol, 1990: 894).

\section{History}

\section{Case Study: Jim Smith}

Jim Smith studied for a business management degree at university from 2002to 2005. Prior to beginning his studies, Jim Smith worked five years for a large company as a lowlevel department supervisor. However, a lack of on-the-job recognition and a feeling that the rewards he was given were not commensurate with the efforts that he was making, meant that he made a decision to go on to further education. Jim Smith knew, however, that he would not be in receipt of any financial assistance whilst he was studying and that, as a result, he would be obliged to support himself throughout his studies. As such, Jim Smith arrived at university anxious to find a suitable means for making enough money to cover his expenses.

By nature a gregarious and inquiring individual, Jim Smith made a number of new friends and acquaintances within his first few weeks at university. It was at a campus party that he noticed a number of students sitting around smoking marijuana. After a long and informative conversation, Jim Smith discovered that the marijuana had been brought to university by one of the students but that the quantity brought was almost exhausted. In addition, the students had remarked that they had no way of obtaining any further supply until they went home for the Christmas break (still three months away). Recognizing a very obvious level of demand and being made aware of supply shortages, Jim Smith quickly made the decision to travel home and find a marijuana supplier that he could trust and who would be prepared to make the long journey to university to deliver the product:

The way I see it there's only two ways to make money at university, well, there's actually three; you can go and work for a retail shop or at a bar and earn four pounds fifty an hour, you can promote nights at local pubs and clubs which is what a lot of students do or you can sell drugs. It was an easy choice for me to make given my previous experience of the retail trade.

Furthermore, Jim Smith expressed the opinion that if he hadn't chosen to become a drug dealer then someone else would have taken his place and fulfilled that function:

If people take drugs, they take drugs-that's the bottom line. If people are smoking marijuana before they come to university, then you can 
pretty much guarantee that sooner or later they will find a new supplier. It just so happens that I noticed the opportunity before they got to meet the incumbent suppliers and so managed to take advantage of the situation.

It was not a difficult decision for Jim Smith to make, especially given his view that this situation presented a very real opportunity for him to make the money he needed to pay his way through his studies:

I think it was about November, October/November, when I started selling in large quantities. When I arrived at university, there were only two guys that you could go to for that sort of thing serving the whole student population. I mean, if you look at it, when I started there, there was maybe eight or nine thousand students, erm, and, I mean, only two people serving that market. I mean, you think, that's not very competitive, you know, it sounded more like a monopoly, really! I think that most people stay well clear from supplying drugs, you know, they're happy enough to consume the products, they're just not prepared to take the associated risks of supplying them.

Although word of mouth was the main driver in the growth and development of the business, Jim Smith also worked hard in actively promoting his products; Jim Smith continually asked the most popular students at the university, members of the students' union as well as the university's leading promoters (of night-club events), to help expand his business by referring as many customers to him as possible. In addition, Jim Smith used his position as a first-year living in university-supplied accommodation to network with his fellow students and to build his customer base as a result:

I was in a great position to exploit the fact that the first-years didn't know the area, didn't know where to go to get their gear and didn't really know anyone outside the first year. This meant that almost immediately I had a firm grip on my customer base. The main problem I had was expanding beyond that set of students, especially getting access to the first-years that didn't live on campus. I used the friendships that I had developed both in class and outside to spread the word that I was the man who could help and, before I knew it, my phone started to ring all hours of the day and night.

Of course, the marketing of illicit products presents a number of very significant challenges. Firstly, traditional marketing channels are not available, and secondly, and perhaps more worrying for the seller, as the business profile grows, so do the chances of being discovered by the authorities. However, when Jim Smith was asked whether he was concerned about being discovered, he replied that he was not. Indeed, during the course of the interview, it became very obvious that, although he was aware of the legal ramifications of being a drug dealer, he felt that what he was doing was not socially unacceptable and that, as a result, the chances of anyone "blowing the whistle" on him were fairly remote:

I stayed away from all of the harder drugs, although I was occasionally asked if I could get hold of them. I think that people really don't mind if someone's selling marijuana and making a few quid on the side. On the other hand, I think people really look down on you if you're selling things like crack or ecstasy and try and stop you from doing it. I wasn't 
really doing anyone any harm and I think people knew that and so didn't

have a problem with me.

As word spread amongst his fellow students, Jim Smith's customer base grew rapidly and he soon found himself incapable of meeting demand (in terms of the time it took for him to visit all of his customers). As a result, Jim Smith made the decision to set up a number of smaller dealers and to begin working as a distributor. Again, this decision resulted in a number of distinct challenges and potential threats to the business and to Jim Smith himself. To counter these new dangers, Jim Smith decided that the best way to conduct matters was to bring all of his dealers together and to try and run the business as a kind of family business. To this end, Jim Smith encouraged his dealers to communicate with one another on a regular basis to discuss any issues/problems that they were having with their clients or with selling their products. In addition, Jim Smith organized bi-weekly meetings where all the dealers would get together over dinner and a few pints of beer. The work spent on developing these relationships was minimal in comparison to the benefits that it brought:

I asked my guys to share their products with each other so that if someone was finding it difficult to sell their gear, the others could take over and shift it for them. This meant that I could make more orders of larger quantities on a more regular basis which was good for all of us. In addition, it was important that my guys didn't try and take their customers from each other, you know, everyone was serving their own little niche, selling to their friends and so on, and so everyone had really good relationships with their clients which meant that there was a lot more trust embedded in the process than there might have been if everyone was just out for themselves.

Building up strong networks of social trust also involved being very open with everyone and not trying to hide anything. The need to be open was particularly pressing when Jim Smith moved into shared accommodation for his second year of studies. All of Jim Smith's flatmates were aware of the fact that he was selling marijuana (though none of them were involved in the business directly), and all of his flatmates had to accept the constant stream of visitors coming to the house at all hours. To limit any sense of annoyance that may have arisen, Jim Smith paid all the communal bills, including utilities and telephone and internet charges, as well as organizing frequent and all-expenses-paid nights out (courtesy of Jim Smith's promoter friends). In return for these payments, Jim Smith's flatmates were happy to tolerate the various goings-on associated with living with a drug dealer as well as, on occasion, passing some marijuana on to the other dealers if Jim Smith was unavailable:

I know I was asking a lot of my flatmates to be using their home as the base for a drug dealing operation. I could have gone and lived on my own, but I didn't want to lose that sense of being at university. I made sure they knew what it would entail before moving in and I reassured them that although I would be holding small quantities, I had arrangements for storing the large deliveries when they arrived so that there was no danger for my flatmates in case of a break-in or a bust.

By the time Jim Smith's studies were nearing completion, his activities as a drug dealer had become known by almost the entire student population. Although Jim Smith felt that this wasn't a problem in terms of his security (and very probably good for business), the constant demands placed on him as a result were overwhelming: 
I had to be on my best behaviour at all times, you know, I had to go out and show my face at all the big evening events, but I had to be careful not to get too drunk in case I did anything silly and upset anybody. It was really difficult trying to keep everyone on my good side to prevent any negativity occurring, you know, it felt like being on a first date all the time. Although all these people were my customers, I felt exposed all the time and so, in some senses, I felt like I was their customer inasmuch as they held so much power over me. It got to be really hard on me and so as I was nearing the end of my time at uni I began to think about packing it all in and concentrating solely on my work.

At approximately the same time as Jim Smith was contemplating cessation of trading, there was a break-in at his house. Although no one could be sure of the motives for the break-in, Jim Smith, in conversation with his flatmates, decided to stop all his activities and to make sure that everyone else knew as well:

I have to be honest, it was really scary and I think it really upset my flatmates a lot. There was no way they would have let me continue dealing from the house even if I wanted to-which I didn't. Although the breakin could have been just bad luck, the fact that it occurred really brought home to me and my flatmates the dangers that I was exposing us all to. I think I was naïve in a lot of ways, you know, I thought I could get in, make some money and get out, but maybe the break-in was a warning against such complacency. I stopped selling immediately and told my dealers that if they wanted to carry on, which I advised against, then they would have to find their own source of supply. As it turned out, lots of people quickly learnt of the break-in and all were supportive of my decision to get out of the business. The thing that struck me the most was that whilst I was selling the drugs I had no problem with doing it, but as soon as I stopped it really made me think about the dangers I had placed myself and others in.

\section{Discussion}

The details of the second case study suggest that the broad promotion of enterprise and entrepreneurship may not always lead to outcomes that are consonant with the assumption of economic and social development. Baumol (1990) argues that conceptualizations of entrepreneurship as a purely economic pursuit are too narrow. Indeed, Baumol (1990: 897-98) argues that such depictions are misleading as they do not consider the wider outcomes that often accompany entrepreneurial activities; "if entrepreneurs are defined, simply, to be persons who are ingenious and creative in finding ways that add value to their own wealth, power, and prestige, then it is to be expected that not all of them will be overly concerned with whether an activity that achieves these goals adds much or little to the social product." Indeed, according to Schramm (2006: 279), although economic incentives may be at the heart of many entrepreneurial endeavors, it is important not to ignore the social outcomes that often arise; for many entrepreneurs "the temptation to set aside ethical standards is always present because the gains are so large for the individual who decides to work outside the rules."

This case study suggests, however, that understanding entrepreneurship as an individual activity does not correspond to real-world accounts of entrepreneurship where there is 
frequently a cited need, certainly if the business is to grow, to involve more and more people in a business. As such, the "temptation to set aside ethical considerations" applies not only to the entrepreneurs themselves, but also to all those individuals who are involved in the enterprise in some way or fashion. Referring back to Etzioni's (1987) notion of societal reality testing, this case study suggests that entrepreneurs who are able to generate sufficient social capital are able to involve people in activities that they would normally have left well alone.

The two case studies are almost polar extremes of what can be achieved at the margins of entrepreneurship. Hill Holt Wood reads very much like a pioneer story where the vision of one family, over many years, began to influence national policy on woodland management and conservation. The case study is concerned with both the margins of what was known and of what was acceptable, but through hard work and perseverance, the unknown became the known and the unacceptable became the accepted. In effect, the margins were redefined in favor of Hill Holt Wood and in favor of the innovations introduced therein. The consequences of this newly acquired endorsement were such that new but similar projects immediately began to spring up across the UK with the full and immediate support of both local and national organizations.

The second case study, on the other hand, demonstrates that entrepreneurs can take advantage of the uncertainty that exists at the margins to further their own levels of personal gain. Furthermore, in doing so, the behaviours and ethical considerations of associated and proximate individuals can be compromised. In such instances, the margins, certainly at a local level, are redrawn again but this time at a cost to society rather than at a gain. Given such activities, it is somewhat disconcerting that the acknowledgement that entrepreneurship is, in some cases, as extractive as it is additional is remarkably absent from the majority of entrepreneurship texts despite some well-founded and astute observations; it is often assumed that an economy of private enterprise has an automatic bias towards [improvement], but this is not so... It has a bias only towards profit" (Hobsbawm, 1969: 40).

Although a great deal of entrepreneurship research does not explore the ethical consequences of entrepreneurial activities, it is clear that many entrepreneurial initiatives do much to influence and shape the behaviours and ethics of the communities within which they occur. The first case study demonstrated, both locally and nationally, that there was a need to increase awareness of the importance of ancient woodlands. The second case study demonstrated that people are prepared to turn a blind eye to the activities of their friends if those activities do not cause them any discomfort or harm. Both case studies suggest that there is still a lot of research that needs to be done to further our understanding of how entrepreneurs shape the social expectations or ethical frameworks within which they operate (Bucar et al., 2003). The skills and capabilities used by the entrepreneurs in the case studies were extremely similar: to further their business pursuits, both parties needed their businesses to be sanctioned by the communities within which they were embedded and both parties had to work very hard to include all the people around them who might assist in the development and expansion of their businesses.

Entrepreneurship is not, as we have seen, limited to the economic domain and has farreaching consequences, although these consequences are often largely hidden and not recognized by the entrepreneurs themselves. In an environment in which an ever-increasing emphasis has been placed on the importance of entrepreneurship, especially within further and higher education institutions, there appears to be a greater need to raise awareness of 
the non-economic impacts and outcomes of entrepreneurial activities and to encourage greater levels of responsibility and accountability. Whether this should be the responsibility of educators or whether the responsibility rests across society and social structures more broadly is not clear. However, what has become increasingly obvious in recent years is that the unfettered pursuit of wealth and success in the guise of entrepreneurship can have disastrous consequences on the communities in which they are situated. On the other hand, as suggested by Etzioni (1987), entrepreneurs can do much to break down ossified societal practices and to usher in new and improved business practices which enrich both the entrepreneurs and the communities within which they are based.

\section{Conclusions}

The central discussion on which this paper has been based-that is, the similarities in approach to entrepreneurship in two very different contexts-has important policy implications. Until now, there has been an assumption that entrepreneurs are engaged primarily in value-adding activities and that value-extracting forms of entrepreneurship can be eradicated from the economic landscape by increasing the level of punishments and chance of detection (Renooy et al., 2004). This paper reveals, however, that if governments adopt such an approach, they may well with one hand deter precisely the types of entrepreneurship and enterprise that, with the other hand through their enterprise culture policies, they are seeking to nurture. Recognizing the integrative and dynamic nature of entrepreneurial behaviours is, therefore, more than simply a matter of academic interest. A fuller and more nuanced understanding of value-extracting entrepreneurs' motives and behaviours is crucial so that appropriate public policy decisions can be taken towards this hidden enterprise culture, such as initiatives to enable these entrepreneurs to legitimise their business ventures rather than solely measures to eradicate these enterprises. If this paper therefore stimulates further studies that evaluate whether there is the same co-presence of opportunity factors and dynamism in entrepreneurs' motives elsewhere, as well as encouraginggreater reflection on what should be done about the prevalence of valueextracting entrepreneurs, then the paper will have fulfilled its objectives.

\section{Contact Information}

For further information on this article contact:

Gerard McElwee, Reader in Rural Enterprise, University of Lincoln, Lincoln, LN6 7RT, United Kingdom.

Tel: $0044(0) 1522886423$

E-mail: gmcelwee@lincoln.ac.uk

\section{References}

Atherton, A. 2004. "Unbundling Enterprise and Entrepreneurship: From Perceptions and Preoccupations to Concept and Practice," International Journal of Entrepreneurship and Innovation 5, no. 2: 121-27.

Baumol, W. 1990. "Entrepreneurship: Productive, Unproductive and Destructive," Journal of Political Economy 98, no. 5: 893-921.

Bucar, B., M. Glas and D. Hisrich. 2003. "Ethics and Entrepreneurs: An International Comparative Study," Journal of Business Venturing 18, no. 2: 261-81.

Buckley, P. and M. Casson. 2001. "The Moral Basis of Global Capitalism: Beyond the Eclectic Theory," International Journal of the Economics of Business 8, no. 2: 303-27.

Cope, J.P. 2003. "Researching Entrepreneurship through Phenomenological Inquiry: Philosophical and Methodological Issues." Working paper LUMSWP2003b/052, Lancaster University.

Etzioni, A. 1987. "Entrepreneurship, Adaptation and Legitimization," Journal of Economic Behavior and Organization 8: 175-89. 
Frith, K. and G. McElwee. 2008a. "The Entrepreneurial Wide Boy: A Modern Morality Tale," International Journal of Entrepreneurship and Small Business 5, no. 5 (forthcoming).

—. 2008b. "An Emergent Entrepreneur? A Story of a Drug Dealer in a Restricted Entrepreneurial Environment," Society and Business Review 3, no. 2: 270-86.

Galloway, L. 2007. "Entrepreneurship and the Gay Minority: Why the Silence?," International Journal of Entrepreneurship and Innovation 8, no. 4: 271-80.

Hannafey, F. 2003. "Entrepreneurship and Ethics: A Literature Review," Journal of Business Ethics 46, no. 2: 99-110.

Harding, R., D. Brooksbank, M. Hart, D. Jones-Evans, J. Levie, J. O'Reilly and J. Walker. 2006. Global Entrepreneurship Monitor United Kingdom 2005. London: London Business School.

Harper, D. 2003. Foundations of Entrepreneurship and Economic Development. New York: Routledge.

Hobsbawm, E. 1969. Industry and Empire from 1750 to the Present Day. Harmondsworth: Penguin.

Kirzner, I. 1973. Competition and Entrepreneurship. Chicago: University of Chicago Press.

Maritz, A. 2004. "New Zealand Necessity Entrepreneurs," International Journal of Entrepreneurship and Small Business 1: 255-64.

Minniti, M., W. Bygrave and E. Autio. 2006. Global Entrepreneurship Monitor: 2005 Executive Report. London: London Business School.

Nodoushani, O. and P.A. Nodoushani. 2000. "Second Thoughts on the Entrepreneurial Myth," International Journal of Entrepreneurship and Innovation 1, no. 1: 7-13.

Perunovic, Z. 2005. Introducing Opportunity-Based Entrepreneurship in a Transition Economy, Policy Brief 39. University of Michigan: The William Davidson Institute.

Rehn, A. and S. Taalas. 2004. "'Znakomstva I Svyazi!' [Acquaintances and Connections]: Blat, the Soviet Union, and Mundane Entrepreneurship," Entrepreneurship and Regional Development 16, no. 3: 235-50.

Renooy P., S. Ivarsson, O. Wusten-Gristai and R. Meijer. 2004. Undeclared Work in an Enlarged Union. European Commission: Directorate-Generale for Employment and Social Affairs.

Schindehutte, M., M. Morris and J. Allen. 2005. "Homosexuality and Entrepreneurship: Implications of Gay Identity for the Venture-Creation Experience," International Journal of Entrepreneurship and Innovation 6, no. $1: 27-40$.

Schramm, C. 2006. "The High Price of Low Ethics: How Corruption Imperils Entrepreneurship and American Democracy," Journal of Markets and Morality 9, no. 2: 277-91.

Schumpeter, J. 1942. Capitalism, Socialism and Democracy. London: Routledge.

Smith, R. 2007. "Special Issue: Listening to Voices from the Margins of Entrepreneurship," International Journal of Entrepreneurship and Innovation 8, no. 4: 245-50.

Storr, V. and B. Butkevich. 2007. "Subalternity and Entrepreneurship: Tales of Marginalised but Enterprising Characters, Oppressive Settings and Haunting Plots," International Journal of Entrepreneurship and Innovation 8, no. 4: 251-60.

Thompson, C., W. Locander and H. Pollio. 1989. "Putting Consumer Experience Back into Consumer Research: The Philosophy and Method of Existential Phenomenology," Journal of Consumer Research 16: 33-146.

Warren, L. 2007. "The Establishment Strikes Back? The Life and Times of Takafumi Horie," International Journal of Entrepreneurship and Innovation 8, no. 4: 261-70.

Wempe, J. 2005 "Ethical Entrepreneurship and Fair Trade," Journal of Business Ethics 60, no. 3: 211-20.

Williams, C.C. 2006. The Hidden Enterprise Culture: Entrepreneurship in the Underground Economy. Cheltenham: Edward Elgar.

- 2008. "Beyond Necessity- Versus Opportunity-driven Entrepreneurship: A Study of Informal Entrepreneurs in England, Russia and Ukraine." International Journal of Entrepreneurship and Innovation 9, no. 3: $157-65$. 